\title{
8
}

\section{Indigenous peoples, neoliberalism and the state: A retreat from rights to 'responsibilisation' via the cashless welfare card}

\author{
Shelley Bielefeld
}

\section{Introduction}

Reflecting on the focus of this edited collection-indigenous rights, recognition, neoliberalism and the state-this chapter will address the reduction of Indigenous peoples' rights in the context of cashless welfare transfers. It contributes to the arguments made in this collection by exploring how neoliberal interventions can adversely affect Indigenous peoples, diminishing their consumer choices and other rights, whilst simultaneously creating benefits for entrepreneurial interests via privatisation of social security payments. It questions the purpose of the government's recognition of the lower socio-economic status of Indigenous peoples and explores who benefits from such recognition. The chapter analyses how cashless welfare transfers operate along racialised contours and implement a neoliberal approach to governance of Indigenous peoples, fostering regulation by market principles that reward entrepreneurialism and self-reliance. Like the work of Deirdre Howard-Wagner, Patrick Sullivan, Cathy Eatock and Alexander Page in this collection, this 
chapter highlights the increasingly precarious experience of Indigenous communities caused by insecure marketised funding arrangements with competitive processes. It progresses these themes by recommending the development of an alternative form of resource redistribution through an integrity tax based on reparation for colonial atrocities. The chapter contends that this approach is preferable to that of intensifying welfare conditionality via cashless welfare transfers.

In 2014, Andrew Forrest recommended that the federal government trial a 'Healthy Welfare Card' with 100 per cent cashless welfare for recipients of government income support except for 'age and veterans' pensions (Forrest 2014: 100-8). Forrest (2014: 102-3) claimed that Australia had 'increased the risk to its most vulnerable by paying all welfare benefits in cash', which enabled an 'incoming tide of drugs and alcohol', particularly in remote Indigenous communities, and that there was a need to 'find a technologically possible, sensible mass solution to end this unnecessary suffering'. Forrest (2014: 105) maintained that the Welfare Card would swiftly move individuals into employment and reduce 'emergency relief payments and crisis services ... through a longer-term reduction in welfare reliance'. Neoliberal notions of increased efficiency and reduced government expenditure on income support were therefore an important aspect of his advocacy for overhauling the Australian welfare system. Forrest (2014: 107) also envisioned that 'existing data mining technology' be used 'to monitor use of the card to detect any unusual sales or purchases, with ... on-the-spot penalties on retailers and individuals for fraudulent use of the card'.

The federal government decided to implement aspects of the Healthy Welfare Card via the Social Security Legislation Amendment (Debit Card Trial) Act 2015 (Cwth) (the DCT Act), with some variations to Forrest's formulation. Initially described by government as the 'Healthy Welfare Card', the epithet they now favour is the 'cashless debit card' (CDC) (Commonwealth of Australia 2015: 2). This corresponds with the government's representation of this card as 'an everyday mainstream debit card' (Commonwealth of Australia 2015: 3). However, critics of the scheme have come up with alternative nomenclature: the 'cashless welfare card' (ACOSS 2014a), 'Welfare Debit Trial Card', the 'Unhealthy Welfare Card', the 'Economic Apartheid Card' (Say NO to the Welfare Debit Card Ceduna') and the 'White Card' (Klein \& Razi 2017: 13).

1 For more information about the Say NO to the Welfare Debit Card Ceduna resistance group, see their Facebook page: www.facebook.com/groups/1486363324991953/?notif_t=group_r2j_approved \&notif_id=1469193406809130. 
Rather than being applied to all welfare recipients, the scheme is being trialled in communities with large numbers of Indigenous welfare recipients: Ceduna, Kununurra and Wyndham (DSS 2016). Indigenous people comprise 565 of the 752 people subject to the Welfare Card in Ceduna and 984 of the 1,199 people on the card in Kununurra and Wyndham (Aboriginal and Torres Strait Islander Social Justice Commissioner 2016: 91-2). Indigenous social security recipients are consequently disproportionately impacted by the Welfare Card, which raises the issue of violation of the right to be free from racial discrimination and other significant rights, including rights to privacy, equality and social security (Gooda 2015, Parliamentary Joint Committee on Human Rights 2015: 24, 27-8).

The DCT Act Explanatory Memorandum (2015) states the trial aims to restrict access to cash to 'reduce the habitual abuse and associated harm resulting from alcohol, gambling and illegal drugs'. Substance abuse has featured heavily in the government's rationalisation for the trial, which unjustly stigmatises trial participants. Yet the Welfare Card does not simply target people with addiction issues. Instead, the card has wide application to welfare recipients residing in geographical locations selected for the trial. There is grassroots resistance in Ceduna to the blanket imposition of the card (Ceduna Anti Card Group 2016, Say NO to the Welfare Debit Card Ceduna), which makes no distinction between the financial capacities or behaviours of affected welfare recipients. The government states that the Welfare Card is being implemented at the behest of Indigenous leaders (Commonwealth of Australia 2015: 2), yet if there was community consent to the scheme there would be no need for broad compulsory application of the card. Indeed, some Indigenous leaders of Ceduna have stressed that there was no support in their communities for the card to be universally applied to all welfare recipients in the region (Smart and Peters in Davey 2017). Rather, they emphasise that any community support was qualified and conditional; however, this ultimately was not reflected in government policy. Similar feedback has been forthcoming from Kununurra (MG Corporation 2017: 1-4).

Although the new legislation allows welfare recipients to voluntarily choose the Welfare Card (DCT Act s. 124PH), there is broad compulsory subjection to the scheme through ministerially determined 'trigger' payments for people of 'a particular class' who reside in 'a particular trial area' (DCT Act s. 124PG). A 'trigger payment' is broadly defined and covers most payment types except for the 'mature age allowance' 
(DCT Act s. 124PD). The amount of restricted income under this new system is 80 per cent of a welfare recipient's payment (DCT Act s. 124PJ). Those subject to the Welfare Card can appeal to a community panel to have the restricted amount reduced to 'a percentage in the range of $50 \%$ to $80 \%$ ' (s. $124 \mathrm{PK}$ ), at the panel's discretion. Feedback from Ceduna indicates that this is a protracted and often unsatisfactory process. Some of those affected have expressed concern that this outsourcing process involves members of the community panel being given substantial power over peoples' lives without providing a rationale for decisions made, intensifying the arbitrary exercise of power (Kakoschke-Moore in Community Affairs Legislation Committee 2016: 98) and surveillance over welfare recipients.

\section{Practical problems and consumer issues}

In the second reading speech introducing the DCT Act, the government claimed that:

the cashless debit card will work as similarly as possible to any other bank card. The trial will seek to ensure the card can work at all existing terminals and shops, except those selling the restricted products of alcohol and gambling, as well as online where possible. The only difference will be that it will not allow the purchase of alcohol and gambling products or allow cash withdrawals (Commonwealth of Australia 2015: 3).

However, feedback from those affected in the trial site of Ceduna indicates that people subject to the card have had trouble paying for items that were meant to be permitted expenditure via the card (Pav in Fedorowytsch \& Iggulden 2016). For example, in May 2016, the Ceduna Anti Card Group met and relayed that there had been problems with people being unable to pay their bills at their local post office with their Welfare Card (Ceduna Anti Card Group 2016). This meant that people were presented with the impossible challenge of trying to pay their bills with their 20 per cent cash allowance. The group reported that many people were experiencing delayed payments of eight to 12 hours by financial services provider Indue Ltd. One person was said to have experienced 'having funds disappear from her card account without her knowledge and permission at the rate of 100 dollars at a time' (Ceduna Anti Card Group 2016). Problems paying off credit cards were also a cause of distress, as this leads to more debt with penalties for overdue payments and additional interest. 
Inability to pay bills normally was reported to create feelings of shame and humiliation (Ceduna Anti Card Group 2016). This led the group to ask 'how are people to pay their bills normally?... Will we have to go and beg every time we need to pay a bill?' (Ceduna Anti Card Group 2016). Further reported problems include people being unable to purchase food during blackouts (ABC Editorial 2016) and people with previously sound rental payment records falling behind in rent due to the card (Haseldine in Gage 2016).

Other concerns include consumer issues. These are twofold. First, those who had previously preferred to pay for items in cash in order to avoid transaction fees are now forced into a situation where they have to pay additional merchant surcharge fees for goods and services because they are paying by card. This is difficult for people already experiencing challenges associated with a low income. The government has not offered to pay these additional sums nor have they prohibited merchants from charging such fees in the trial sites or in Australia more broadly. This means that the cashless welfare card makes social security income more expensive for welfare recipients to use. This is a crucial point that has not been addressed satisfactorily by the government. When the issue of diminished consumer rights under the Welfare Card was drawn to the attention of Alan Tudge, the Minister for Human Services, he denied that this was the case, pointing out that 'of the 16 merchants in Ceduna with surcharges or minimum spends, only eight will continue to implement these fees' (Tudge 2016: 3). Yet those additional merchant charges from even eight outlets are enough to break a budget for welfare recipients living on below 'poverty line' payments (ACOSS 2014b: 8). Moreover, like other members of Australian society, welfare recipients travel when seeking employment and maintaining relationships necessary for social inclusion. Extra costs due to card surcharges associated with such travel could well increase difficulties for those on low incomes, as occurs with compulsory income management in the Northern Territory (Bray et al. 2014: 136-7).

The second consumer issue is that people who had previously been free to choose the banking service into which their social security payments were made are now coerced to have a contractual relationship with Indue Ltd, a financial services provider that is not a bank. Indue does not offer the range of accounts to suit low-income earners that banks have developed. When contacted about these issues by the CEO of the Consumer Action Law Centre, Gerard Brody, the CEO of the Australian Bankers Association (2016) Steven Münchenburg responded that: 
consumer choice is a valuable right which should be protected and choosing the right banking product or service that is suitable to individual needs should continue to be a pivotal consideration. Currently, some Australian banks offer 'basic bank accounts' that are suitable for disadvantaged and low-income customers and the banking industry strongly supports the promotion of these accounts. The ABA [Australian Bankers Association] also supports ensuring competition in the market which is most likely to lead to innovations that maximise consumer choices. (Australian Bankers Association 2016)

Instead of fostering consumer choice, the government has created a captured market for Indue Ltd as the entity charged with orchestrating this new technological 'panopticon', where those subject to the Welfare Card are under omnipresent inspection (Bentham 1995: 31, 43-5). This has led to strongly worded concerns. For instance, David Tennant (2015) has suggested that this move may lead to 'a new banking underclass' in Australia.

\section{Who benefits?}

The launch of the cashless welfare card raises significant questions. Given that the concept was derived from Forrest's Indigenous jobs and training review, it must be asked for what purpose is the lower socioeconomic status of Indigenous people recognised and who benefits from such recognition? Indue Ltd's early stage contract figures were AU $\$ 2,870,675.50$ for the CDC IT build and a further contract of AU\$7,939,809 for implementation of the CDC trial. ${ }^{2}$ These sums were part of a reported AU $\$ 18.9$ million (excluding GST) allocated to the CDC, costing approximately AU $\$ 10,000$ per participant (Conifer 2017). Considering that this was for a trial of the cashless welfare card for no more than 10,000 welfare recipients (Explanatory Memorandum 2015: 4) from '1 February 2016' to '30 June 2018' (DCT Act s. 124 $\mathrm{PF}$ ), this sum is hefty indeed. Indue Ltd's implementation contract has since risen to AU $\$ 13,035,581.16 .^{3}$ If this trial is expanded then Indue Ltd and possibly other like institutions will stand to benefit considerably as Australia's social security payments are privatised. This fits with 'the

2 The reference numbers for these contracts between the Department of Social Services and Indue Ltd are CN3323493-A1 and CN3290604 respectively, published on AusTender, www.tenders.gov.au.

3 Reference number CN3323493-A2, published on AusTender, www.tenders.gov.au. 
normative neoliberal vision of market provision' of services traditionally provided by governments (Cahill 2014: 27, 54). That the government has an eye towards this possibility is signalled by the second reading speech, which states that 'The trial ... will make a vital contribution towards informing ... future arrangements for income management' (Commonwealth of Australia 2015: 3).

While the benefits of the CDC for Indue Ltd are clear, the same cannot be said for government income support recipients subject to the card. The Final Evaluation report on the CDC by Orima consultants (DSS 2017a) reveals some troubling consequences for numerous cardholders who participated in the surveys. These include increased difficulties paying bills, running 'out of money to buy food', problems paying for housing needs, having insufficient funds to pay for educational items for children, and running out of money to pay for essentials for children (e.g. 'nappies, clothes and medicine') (DSS 2017a: 72). Other problems included card malfunction, inability to participate as desired in the cash-based economy, trouble checking card account balances, some merchants refusing to accept the card for purchase of everyday items, and embarrassment when the card does not work (DSS 2017a: 89). Unsurprisingly, 32 per cent of card users said the CDC 'had made their lives worse' (DSS 2017a: 6). None of these problems have been emphasised by government in their media releases on the card. Also, significant given the government rationale for the card, the majority of CDC participants reported either no change in alcohol consumption, gambling or illegal drug use since using the CDC or an increase in these behaviours (DSS 2017a: 43).

For numerous welfare recipients subject to it, the coercive nature of the CDC may impair any possible benefits envisioned by government because health research indicates that autonomy is a core human need directly linked with favourable health outcomes. Marmot (2015: 249) indicates that 'control over one's life and opportunities for meaningful social engagement are necessary for health'. He contends (2015: 248) that '[a]utonomy and social participation are so important for health that their lack leads to deterioration in health'. Autonomy is clearly undermined by the cashless welfare card, which denies users freedom of choice and, as previously mentioned, the additional cost of living incurred by those who use the card may also detrimentally affect their capacity for social inclusion. Mick Gooda (2015) also contends that '[a]ny possible benefits must be weighed against the sense of disempowerment people report, the stigma they feel and punitive perceptions'. 
It has been noted by the Parliamentary Joint Committee on Human Rights (2015: 23) that the cashless welfare card 'is very similar to the existing program of income management' currently operating in the Northern Territory and other select trial areas in Australia. Empirical research reveals that income management is ineffective in 'changing people's behaviours' or 'spending patterns, including food and alcohol sales' (Bray et al. 2014: xxi). Nor does income management facilitate 'improvement in financial wellbeing ... reductions in financial harassment or improved financial management skills' (Bray et al. 2014: xxi). There is also no robust evidence to suggest that community wellbeing has been enhanced by compulsory forms of income management (Bray et al. 2014: xxi, Hunt 2017: 2-3).

The cashless welfare card has the same deficiency-based philosophical foundation as the income management system that has now had an extremely protracted trial for thousands of (mostly) Indigenous welfare recipients in various trial sites. As of 25 August 2017, 79 per cent of the 25,009 welfare recipients nationwide subject to income management identified as Indigenous (DSS 2017b). According to this 'deficit' model, any socio-economic vulnerability experienced by welfare recipients is due to their irresponsible spending patterns. This is a misrepresentation of the budgetary capacity of many welfare recipients and constitutes simplistic and destructive negative stereotyping. Nevertheless, this 'deficit'-based dynamic is consistent with broader neoliberal Indigenous policy trends in Australia, elaborated upon by numerous scholars, who highlight how this model assumes that coercive disciplinarian interventions are warranted to reshape behaviours of Indigenous peoples (Walter 2009: 7, 11-12, Watson 2009: 89, Howard-Wagner \& Kelly 2011: 115, 120, Altman 2013: 88-9, 116, 139, Lovell 2014: 234, Strakosch 2015: 88-90, 105, 134). This approach has clear benefits for government in terms of reinforcement of state power over Indigenous peoples. The language of Indigenous deficiency allows the state to obscure the complexities 'of Aboriginal disadvantage and its own complicity in the maintenance of such poverty and disadvantage' (Walter 2009: 12, also see Watson 2009: 90-1). 


\section{Neoliberalism and responsibilisation: The antithesis of necessary reparations for First Peoples}

As previously mentioned, the government's rationale for implementing the Welfare Card is that it is to reduce 'the social harm caused by welfare-fuelled alcohol, gambling and drug abuse' (Commonwealth of Australia 2015: 2). This portrayal of welfare income and welfare recipients as problems requiring intensive regulation is a long familiar theme of neoliberal governance, whereby the poor are portrayed as the sole authors of their impoverished circumstances. Within this framework, they are tasked with 'responsibilisation', urged to take responsibility for their failure to flourish in 'the neoliberal race to riches', and charged with the task of 'undertaking the correct strategies of self-investment and entrepreneurship for thriving and surviving' (Brown 2015: 24, 133). Wendy Brown (2015: 133) explains that responsibilisation 'discursively denigrates dependency and practically negates collective provisioning for existence' whilst situating 'the individual as the only relevant and wholly accountable actor'.

The Welfare Card reflects neoliberal governmentality in that the aim of 'responsibilisation' is to reconstitute and reorient individuals 'for a neoliberal order' (Brown 2015: 133). Foucault (2008: 145) points out that neoliberal governance aims not to 'correct the destructive effects of the market on society' but instead to facilitate 'regulation of society by the market'. He highlights that for neoliberals, '[t] he homo oeconomicus sought after is not the man of exchange or man the consumer; he is the man of enterprise and production' (Foucault 2008: 147). This perhaps explains why Australia's cashless welfare card architects tend to trivialise or ignore the reduction of consumer rights for income-managed welfare recipients. If entrepreneurial interests require that consumer rights are diminished in their pursuit of profit then neoliberal governments are accommodating.

The objective of neoliberal governmentality is to construct homo oeconomicus as 'someone who is eminently governable' (Foucault 2008: 270); and, as Edward Said (1994: 327) notes, '[t] o be governed people must be ... ruled in regulated places'. Whilst Australia's consumer landscape has long been regulated, cashless welfare card transfers add rocky new terrain where welfare recipients are differentiated in public places and exposed 
to greater stigma and surveillance. ${ }^{4}$ This is aligned with neoliberalism's continuous 'institutional transformation, involving ... destruction and reconstruction of regulatory architectures, and the overlaying of these upon existing institutions' (Cahill 2014: 28). This ushers in what Peck describes as 'neoliberalisation' with 'an open-ended and contradictory process of politically assisted market rule' (Peck 2012: xii). Thus, in the name of creating more autonomous subjects, the autonomy of welfare recipients is undermined.

Indigenous welfare recipients who do not conform to the neoliberal ideal of homo oeconomicus have been portrayed as deficient, irresponsible and antisocial (Moreton-Robinson 2009: 70). They have been represented as particularly in need of the intensive regulation offered by the Welfare Card (Commonwealth of Australia 2015:2) and of income management via the BasicsCard (Bielefeld 2014: 287-289). This is part of a broader welfare reform agenda to decrease the number of people in receipt of government income support by ensuring that 'income from work' is 'more favourably treated than income from other sources' (DSS 2014: 9).

Welfare conditionality programs like income management via the BasicsCard and the cashless welfare card also expose a neoliberal fixation on return for investment. Foucault (2008: 256) explains that 'according to the neoliberal theory of consumption', society is portrayed as 'the producer of conforming behaviour with which it is satisfied in return for a certain investment'. Thus, there has been an intensification of welfare conditionality in order to create a political impression that it facilitates the production of conforming behaviour. In a colonial context, this amounts to a quest to complete the government's long cherished ideal of assimilation of Indigenous peoples. In terms of neoliberal governance, where disadvantage remains, this is seen as an outcome for which Indigenous peoples are to take 'responsibility' (Watson 2009: 90).

While 'disciplining Indigenous life to the cold rationality of market principles' (Coulthard 2014: 13) has long featured in colonial projects, neoliberal governance proffers new challenges for Indigenous peoples as they are confronted with a host of proposals that are '[p] unitive ... and

4 The effortless public identification of Indue card holders engaging in purchases has been confirmed by fieldwork conducted in the East Kimberley. Klein and Razi (2017: 12) note the presence of separate cash registers in some venues that must be used by CDC users. 
obsessed with employment despite the absence of good jobs' (Fraser 2013: 113). Such policies foster insecurity for the most marginalised while cementing elite privilege.

Colonial governments are well served by neoliberal governmentality because its ahistoricism allows accumulated layers of privilege and disadvantage to be left undisturbed. However, there is a need to critique the filters through which we attempt to comprehend causes of poverty and possibilities for its redress. To position the socio-economic challenges Indigenous communities experience as the consequence of pathological individual or community behaviour can detract focus from significant structural factors contributing to poverty. Structural contributors include the paucity of adequately paid employment in remote communities and lingering legacies of colonialism that have resulted in underfunded essential services for Indigenous communities (Altman 2013: 40, Watson 2009: 90-1). Interventions such as the Welfare Card also arguably distract attention away from alternative redistributive possibilities, such as a reparations fund for Australia's First Peoples based on their experience of colonial atrocities. This is characteristic of Australia, where there has been a 'long tradition of framing domestic welfare policy as the "solution" to settler colonial conflicts' (Strakosch 2015: 3).

Yet, such framing need not be treated as inevitable. An alternative type of policy framing is possible. For instance, James Ferguson (2015: 10, 165) proposes that a new 'politics of distribution' be developed where resource redistribution is based on the concept of the 'rightful share'. This is important in colonial contexts worldwide where government and corporate interests continue to profit vastly from mineral extraction and other exploitative enterprises while millions of people who have undergone the nightmare of colonisation remain greatly impoverished. Ferguson (2015:26) explains that according to the rightful share approach:

Distributive claims ... are rooted in a conviction that citizens (and particularly poor and black citizens) are the rightful owners of a vast national wealth (including mineral wealth) of which they have been unjustly deprived through a historic process of racialized dispossession - a conception that provides a very different, and much more politicized, justification for cash payments than is available in the usual framework of 'social assistance' as generous help for the needy. 
If adopted in Australia, this framework would likely improve the socioeconomic circumstances of remote living Indigenous peoples, including those currently subject to a range of punitive welfare conditionality programs in addition to income management, such as penalty-heavy workfare imposed as part of the Community Development Program (Fowkes \& Sanders 2016: 10). Welfare conditionality programs individualise responsibility for 'structural violence' (Bielefeld 2014/2015: 99-118). They are therefore incapable of addressing the root causes of socio-economic disadvantage. Something else is necessary.

Drawing inspiration from an international context, a possible reparation funding model can be seen in the Dene/Métis proposal put to the Canadian government, that 'to ensure economic self-sufficiency ... 10 per cent of all resource revenues derived in the territory be collected and paid into a "Dene Heritage Fund" managed by the Dene' (Coulthard 2014: 74). The Dene/Métis stipulated that national resource use should encompass 'a "firm commitment to renewables"' and that use of non-renewables only be permitted if the "well-being of the people and resources of Denendeh" were ensured (Coulthard 2014: 74). The Dene argued for this economic reparation model in relation to their traditional lands. This could be considered as a type of 'integrity tax' owed by colonial governments to First Peoples as part of a process of decolonisation. It is a concept that may well resonate across multiple jurisdictions where indigenous peoples continue to experience ongoing socio-economic deprivation.

In the Australian Indigenous policy context, Virginia Marshall has suggested a somewhat similar idea with respect to water resources. She contends that 'the concept of water royalties' should 'be included in the policy framework on Aboriginal water rights' (Marshall 2017: 163). Marshall (2017: 163) explains that '[a] water royalty would ensure certainty in economic planning in Aboriginal communities where third parties seek to access and use water on Aboriginal owned lands'. This is one way to ensure Indigenous peoples' access to ongoing economic resources - without the multitude of hoops imposed by oppressive and stigmatising welfare conditionality policy frameworks. This is important because the combination of welfare conditionality programs presently affecting Indigenous peoples 'replicates past discriminatory treatment they experienced as non-citizen wards of the state: ineligible for award wages and paid in kind with rations rather than cash' (Altman 2017). 
If Australia is to attain a genuinely postcolonial status, then redressing the power imbalance over Indigenous peoples' access to economic resources is essential. Application of this integrity tax principle in Australia has the potential to address Indigenous socio-economic disadvantage in a way that bolsters Indigenous self-determination. Nationwide application is crucial in order to account for the effects of colonial dispossession, with many Indigenous peoples being forced off their lands, and practices of coerced child removal resulting in the Stolen Generations. When political elites bemoan that Indigenous peoples do not contribute enough economically, they exclude a highly significant contribution that Indigenous peoples have made to Australia's economy-their land and their forced labour (Bielefeld 2014/2015: 100-3).

In Australia, this integrity tax could be derived from a percentage of resource revenues obtained within the nation, including renewable energy and water resources, subject to the caveats Australia's First Peoples thought appropriate. Repressive regulation in the form of welfare conditionality embodies coloniality and neoliberal governmentality. This integrity tax could potentially provide a pathway out of current approaches designed to colonise, regulate and subjugate Indigenous peoples. It may provide a way to sustain long-term funding for Indigenous communities and end the destructive cycle of endless grant applications for short-term funding under competitive schemes like the Indigenous Advancement Strategy (IAS). The IAS funding fiasco that resulted in major fiscal shortfalls for Indigenous run organisations is aptly critiqued by Alexander Page in this edited collection (see Chapter 10).

While space does not permit full elaboration of how these integrity tax ideas might be implemented, further work on alternative frameworks to poverty surveillance and welfare conditionality will be facilitated by the author's Australian Research Council-funded project in coming years. ${ }^{5}$ Preliminary analysis suggests that any Australian reparations fund would need to be controlled by Indigenous communities, not by the state. The Aboriginals Benefit Account (ABA) stands as a cautionary tale of what can occur when government has control over such finances. The ABA is a scheme by which a percentage of mining royalties from Aboriginal lands in the Northern Territory are placed in an account for the benefit of Indigenous communities. The use of the ABA to facilitate 99-year

5 ARC DECRA, 'Regulation and Governance for Indigenous Welfare: Poverty Surveillance and its Alternatives' (DE180100599). 
leases of Aboriginal lands back to the federal government in exchange for essential services has met with merited criticism (Altman 2013: 98, Altman 2014: 135-6). Indeed, it could be seen as the federal government unconscionably requiring Indigenous landholders to ransom their land in exchange for essential services available to other citizens without like conditions.

\section{Conclusion}

Arguably the cashless welfare card is a new technology of power reinscribing a long-established socio-economic hierarchy with racialised consequences. Yet, Australia needs ' $[\mathrm{a}] \mathrm{n}$ ambitious plan to redress injustice' rather than 'simply managing inequality with the latest tools from economists and technocrats' (Farmer 2005: 244-5). Alternative forms of resource redistribution ought to be explored rather than engaging in expensive intensive surveillance that is central to welfare conditionality. The cashless welfare card consumes scarce resources based upon an unproven assumption that welfare recipients are untrustworthy/deviant subjects who require constant paternalistic oversight. Resource-intensive income management reforms are unlikely to cut long-term costs if that is the government's aim.

There are many questions that remain as to what the cashless welfare card will achieve. Is this Welfare Card yet another example of colonial powers 'co-opting Indigenous Peoples' (Watson 2015: 3) into their regulatory regimes? And, if so, at what price? What other possibilities are not explored if the Welfare Card is presented as the poverty solution? Although the federal government and Forrest assert that the Welfare Card is a modern mechanism to address socio-economic disadvantage, and a Senate Inquiry has recently recommended its expansion (Senate Community Affairs Legislation Committee 2017: 29), ${ }^{6}$ the CDC can more credibly be understood as yet another regulatory intervention designed to impose a Eurocentric and neoliberal script. In the East Kimberley, this is reflected in the reframing of the CDC by those forced to use it - they describe it as the 'White Card' due to it being 'imposed by white people' (Klein \& Razi 2017: 13).

6 With dissenting reports by the Labor Committee members (Senators Lisa Singh and Murray Watt) and the Greens Committee member (Senator Rachel Siewert). 
The preliminary work undertaken by the cashless welfare card is considerable. First, by pathologising poverty it rationalises existing economic injustices, what Bourdieu (1998: 98, 62) refers to as 'the structural violence of unemployment' and 'the uncontrolled violence of ... markets'. Second, it creates a new industry for 'poverty profiteers' (Bielefeld 2017:31) to mine as other geographically land-based mines face a future of inevitable exhaustion. This is one way of understanding why a mining magnate such as Forrest was chosen by the federal government for the Indigenous jobs and training review and why government has been willing to adopt his recommendation for a welfare system overhaul, despite this recommendation clearly being outside the terms of reference of that review. Third, it forecloses discussion about alternative redistributive possibilities, such as a reparations fund for Australia's First Peoples. However, a reparations framework for Australia's First Peoples funded by the kind of integrity tax outlined in this chapter is preferable to shoring up existing inequality via technological panopticonism, and a new 'politics of distribution' (Ferguson 2015: 10) is arguably long overdue.

\section{Acknowledgements}

The author thanks the 'Indigenous Rights, Recognition and the State in the Neoliberal Age' symposium participants for their stimulating and helpful feedback on an earlier draft.

\section{References}

ABC Editorial (2016). Blackout causes 'mayhem' in Ceduna as phones, internet and eftpos cut. $A B C$ News, 10 September, www.abc.net.au/news/2016-0910/families-leave-food-in-supermarket-after-eftpos-blackout/7833338.

Aboriginal and Torres Strait Islander Social Justice Commissioner (2016). Social justice and native title report 2016, Australian Human Rights Commission, Sydney.

ACOSS (Australian Council of Social Service) (2014a). Groups call for rejection of Healthy Welfare Card: Joint statement. 13 December, www.acoss.org.au/media _release/groups_call_for_rejection_of_forrest_review_healthy_welfare_card.

ACOSS (2014b). Poverty in Australia 2014, ACOSS, Redfern.

Altman JC (2013). Arguing the Intervention. Journal of Indigenous Policy 14:1-151. 
Altman JC (2014). Tracking Indigenous policy, 2011-2014. Journal of Indigenous Policy 15:1-155.

Altman JC (2017). Modern slavery in remote Australia? Arena Magazine, arena.org.au/modern-slavery-in-remote-australia-by-jon-altman/.

Australian Bankers Association (2016). Correspondence by letter from Steven Münchenburg CEO of the Australian Bankers Association to Gerard Brody CEO of the Consumer Action Law Centre, 7 July.

Bentham J (1995). The Panopticon writings, Verso, London \& New York.

Bielefeld S (2014). Income management and indigenous peoples-nudged into a stronger future? Griffith Law Review 23(2):285-317, doi.org/10.1080/103 83441.2014.979421.

Bielefeld S (2014/2015). Compulsory income management, Indigenous peoples and structural violence-implications for citizenship and autonomy. Australian Indigenous Law Review 18(1):99-118.

Bielefeld S (2017). Cashless welfare cards: Controlling spending patterns to what end? Indigenous Law Bulletin 8(29):28-32.

Bourdieu P (1998). Acts of resistance-against the tyranny of the market, The New Press, New York.

Bray J, Gray M, Hand K \& Katz I (2014). Evaluating new income management in the Northern Territory: The final report, Social Policy Research Centre UNSW, Sydney.

Brown W (2015). Undoing the demos: Neoliberalism's stealth revolution, Zone Books, New York.

Cahill D (2014). The end of laissez-faire? On the durability of embedded neoliberalism, Edward Elgar Publishing, Gloucestershire \& Massachusetts.

Ceduna Anti Card Group (2016), email correspondence from group member to the Keep Income Management Accountable Network, 7 May.

Commonwealth of Australia (2015). Parliamentary Debates, House of Representatives, 19 August (Alan Tudge, Parliamentary Secretary to the Prime Minister).

Community Affairs Legislation Committee (2016). Senate Estimates, 20 October (Skye Kakoschke-Moore, Senator for South Australia). 
Conifer D (2017). Centrelink cashless welfare card trial costing taxpayers $\$ 10,000$ per participant, $A B C$ Radio, 2 May, www.abc.net.au/news/2017-05$02 /$ cashless-welfare-trial-costing-taxpayers-\$10k-per-participant/8488268.

Coulthard GS (2014). Red skins, white masks: Rejecting the colonial politics of recognition, University of Minnesota Press, Minnesota \& London, doi.org/ 10.5749/minnesota/9780816679645.001.0001.

Davey M (2017). 'Ration days again': Cashless welfare card ignites shame, Guardian, 9 January, www.theguardian.com/australia-news/2017/jan/09/ ration-days-again-cashless-welfare-card-ignites-shame.

DSS (Department of Social Services) (2014). A new system for better employment and social outcomes - Interim report of the reference group on welfare reform to the minister for social services, Commonwealth of Australia, Canberra.

DSS (2016). Cashless debit card trial-Overview, DSS, Canberra, www.dss. gov.au/families-and-children/programmes-services/welfare-conditionality/ cashless-debit-card-trial-overview.

DSS (2017a). Cashless debit card trial evaluation: Final evaluation report, Orima Research, Canberra.

DSS (2017b). Income management and cashless debit card summary (25 August 2017), DSS, Canberra, www.data.gov.au/dataset/income-managementsummary-data/resource/b898777c-8a2b-4094-b378-cdb48346a110.

Explanatory Memorandum (2015). Social Security Legislation Amendment (Debit Card Trial) Bill 2015 (Cth), parlinfo.aph.gov.au/parlInfo/download/ legislation/ems/r5520_ems_91404ffb-3b40-4be1-a67e-2c5f2e6a 1eeb/ upload_pdf/503546.pdf.

Farmer P (2005). Pathologies of power: Health, human rights and the new war on the poor, University of California Press, Berkeley, Los Angeles \& London.

Fedorowytsch T \& Iggulden T (2016). Malcolm Turnbull praises cashless welfare card trial on Ceduna visit. $A B C$ News, 31 October, www.abc.net.au/ news/2016-10-30/malcolm-turnbull-praises-cashless-welfare-card-trial-inceduna/7978758.

Ferguson J (2015). Give a man a fish: Reflections on the new politics of distribution, Duke University Press, Durham \& London, doi.org/10.1215/ 9780822375524 .

Forrest A (2014). Forrest review: Creating parity. Report to the Commonwealth of Australia, Canberra. 
Foucault M (2008). The birth of biopolitics: Lectures at the College De France 1978-1979, Palgrave Macmillan, New York.

Fowkes L \& Sanders W (2016). Financial penalties under the Remote Jobs and Communities Program. Working Paper No. 108, Centre for Aboriginal Economic Policy Research, The Australian National University, Canberra.

Fraser N (2013). Fortunes offeminism: From state-managed capitalism to neoliberal crisis, Verso, London.

Gage N (2016). Ceduna's cashless welfare card a 'massive inconvenience', but council sees improvements. $A B C$ News, 12 September, www.abc.net.au/news/ 2016-09-12/ceduna-cashless-welfare-card-'massive-inconvenience'/7836942.

Gooda M (2015). Cashless welfare card opens old wounds for Indigenous Australians. The Drum, ABC News, 16 October, www.abc.net.au/news/ 2015-10-16/gooda-healthy-welfare-card-opens-old-wounds-for-indigenous/ 6859588.

Howard-Wagner D \& Kelly B (2011). Containing Aboriginal mobility in the Northern Territory: From 'protectionism' to 'interventionism'. Law Text Culture 15:102-34.

Hunt J (2017). The cashless debit card evaluation: Does it really prove success? Topical Issue 2/2017, Centre for Aboriginal Economic Policy Research, The Australian National University, Canberra.

Klein E \& Razi S (2017). The cashless debit card trial in the East Kimberley. Working Paper No. 121, Centre for Aboriginal Economic Policy Research, The Australian National University, Canberra.

Lovell M (2014). Languages of neoliberal critique: The production of coercive government in the Northern Territory intervention. In Uhr J and Walter R (eds), Studies in Australian political rhetoric, ANU Press, Canberra, doi.org/ 10.22459/SAPR.09.2014.11.

Marmot M (2015). Status syndrome: How your place on the social gradient directly affects your health, Bloomsbury, London, Oxford, New York, New Delhi \& Sydney.

Marshall V (2017). Overturning aqua nullius: Securing Aboriginal water rights, Aboriginal Studies Press, Canberra.

MG Corporation (2017). Submission No 6 to the Senate Standing Committee on Community Affairs, Social Services Legislation Amendment (Cashless Debit Card) Bill 2017, October. 
Moreton-Robinson A (2009). Imagining the good Indigenous citizen: Race war and the pathology of patriarchal White sovereignty. Cultural Studies Review 15(2):61-79, doi.org/10.5130/csr.v15i2.2038.

Parliamentary Joint Committee on Human Rights (2015). Human rights scrutiny report: Twenty-seventh report of the 44 th parliament, 8 September, Canberra.

Peck J (2012). Constructions of neoliberal reason, Oxford University Press, Oxford.

Said E (1994). Culture and imperialism, Vintage Books, New York.

Senate Community Affairs Legislation Committee (2017). Social Services Legislation Amendment (Cashless Debit Card) Bill 2017. Commonwealth of Australia, Canberra.

Strakosch E (2015). Neoliberal Indigenous policy: Settler colonialism and the 'post-welfare' state, Palgrave Macmillan, Hampshire, doi.org/10.1057/ 9781137405418.

Tennant D (2015). Is the cashless welfare card the forerunner to a banking underclass? Pro Bono Australia, 29 October, www.probonoaustralia.com.au/ news/2015/10/cashless-welfare-card-forerunner-banking-underclass.

Tudge A (2016). Correspondence by letter to Simon Schrapel, 6 May.

Walter, M (2009). An economy of poverty? Power and the domain of Aboriginality. International Journal of Critical Indigenous Studies 2.

Watson I (2015). Aboriginal peoples, colonialism and international law: Raw law, Routledge, Abingdon \& New York.

Watson V (2009). From the 'quiet revolution' to 'crisis' in Australian Indigenous affairs. Cultural Studies Review, 15(1):88-109, doi.org/10.5130/csr.v15i1. 2055 . 
This text is taken from The Neoliberal State, Recognition and Indigenous Rights: New paternalism to new imaginings, edited by Deirdre Howard-Wagner, Maria Bargh and Isabel AltamiranoJiménez, published 2018 by ANU Press, The Australian National University, Canberra, Australia.

doi.org/10.22459/CAEPR40.07.2018.08 